\title{
Introduction
}

\section{Karl Socher}

When the international institutions were created at the Bretton Woods conference at the end of World War II, the most important aims had been to help reconstruction after the war and to create a framework for economic stability, development and growth. Growth and development are necessary (but not sufficient) conditions for reducing poverty, so this aim had already been included in the goals of Bretton Woods institutions at their foundation. However, the aim of reducing poverty had not originally played the central role in the process of developing the strategies of the international institutions because it was believed that, included in the aim of reconstruction and development, economic growth in these war-torn and underdeveloped countries would be a basis to diminish both poverty and also the difference in per capita income between the poor and the rich countries. But in reality these aims have not been reached sufficiently. Therefore the issue of poverty reduction has risen to become a primary goal of international institutions.

The aim of the third CSI conference was to discuss the controversial questions raised by critical economists in academia and non-governmental organizations (NGOs) about the effective strategies for fighting poverty.

The contributions in this book are organized in three parts as follows:

1. The first part deals with general issues about the role of international institutions in economic growth and raising the standard of living in developing countries;

2. The second part looks into the role of particular international institutions in poverty reduction;

3. The third part deals with the role of international institutions in economic development and poverty reduction in the following regions: Eastern Europe, Russia, South-East Asia and the Sub-Sahara. 


\section{PART I: GENERAL ISSUES: INTERNATIONAL INSTITUTIONS AND POVERTY}

\section{Chapter 1: Economic Development and Povery Reduction in the Developing World}

In his first contribution John-ren Chen deals with the general problems of developing countries. Empirical evidence has shown that the performance of economic development has been better in countries which have integrated into the global economy, for instance, the Tiger states. International institutions have helped to liberalize cross-border trade in goods and services (GATT), to provide a sound global payments system and to create global capital markets (International Monetary Fund and World Bank). The provision of these global public goods, however, has been far from efficient. The liberalization of services is going on very slowly, and the international financial architecture is still vulnerable. Free trade in general is welfare-improving. However, the basic assumptions of neo-classical trade theory do not always exist in the real world: for instance, a lot of markets are not perfect, there is long-term unemployment, most adjustment processes such as transition problems are far from smooth, and the necessary compensation of the losers by the winners to justify the welfare gains of free trade (the compensation principle applied by neo-classical international economics to argue the superiority of free trade over autarky) is lacking in most cases. The volatility of primary commodities together with the deteriorating terms of trade is not solved, and crises are not only caused by external factors but partly by government failures or market failures.

Governments of sovereign states are mainly responsible for economic development. The international institutions can only carry out assistant functions to support governments of sovereign states to improve allocation of resources, to create and to reform the institutions, such as the rule of law for property rights and contract laws for the functioning of the market and the provisions for public goods, internalization of externalities and dealing with other market failures. However, there is no 'one-size-fits-all' development policy for the developing countries. Each country needs an individual therapy of development policy.

In the last section of his contribution the author deals with export processing zones - a development policy measure - as effective experiments for developing countries as well as transition countries to learn about the working of a market system. 


\section{Chapter 2: Raising the Standard of Living}

In this chapter John-ren Chen comes to the conclusion that international institutions have to play a much more important role in raising the standard of living because there are still famines, poverty, denial of human rights, civil war, infectious diseases and so on.

He defines the standard of living as including not only the GDP per capita but also non-pecuniary circumstances for well-being, such as the length of life expectancy, health, education, human rights and political participation. To raise this standard of living, international institutions exist which specialize in fulfilling particular functions with respect to these indicators of the standard of living. These functions are complementary to each other. Therefore a higher efficiency of the measures of these institutions can be reached by a better coordination of international institutions. John-ren Chen then discusses the possibility of increasing the efficiency of measures of international institutions in the field of economic and non-economic factors by more efficient markets and providing global public goods:

- one of the most important economic factors would be the abolition of protectionism in agriculture. In an Appendix he proves the Singer thesis, that is, that protectionist measures deteriorate the terms of trade for the developing countries;

- security and peacekeeping by the UN;

- economic stability in goods and financial markets by GATT/WTO and IMF;

- production and use of knowledge, especially about good governance;

- humanitarian assistance: for instance, in famine relief by international emergency food reserves, or protection of human rights, for instance, by the creation of international courts;

- global health (avoidance of contagious diseases); and

- political stability and democracy as measures for avoiding crises, corruption and famine.

John-ren Chen closes with the statement that the task of the study of international institutions is especially to show what role they could fulfil and how this role is to be played in the development of the developing world.

\section{Chapter 3: Growth and Stability as Challenges}

The governor of the Austrian Nationalbank and governor in the IMF for Austria, Klaus Liebscher, describes the different elements of the strategy of international institutions to reduce poverty: the UN Millenium Development 
Goals with their eight key areas, the partnership for development of the international conference on Financing for Development (Monterrey 2002) and the efforts of the IMF and WB with the Poverty Reduction Strategy and special measures for debt relief for the Highly Indebted Poor Countries. With these strategies, the IMF approach to low-income countries changed by launching the Poverty Reduction and Growth Facility, making poverty reduction a key objective. These initiatives of the Fund have become an integral part of the efforts of other international institutions such as the World Bank. These new approaches include more collaboration with the governments of the poor countries in designing the strategies for their better governance and best practices by donor countries under the guidance of the OECD Development Aid Committee (DAC).

A main part of the paper deals with the importance of financial stability for the reduction of poverty. Poor countries, and especially the poor part of their population, are hit more than developed countries by financial crises. Some progress has been achieved by international cooperation and international institutions to overcome crises and also to prevent future crises. Cooperation between the Fed and the ECB prevented a major crisis after September 11. The Financial Stability Forum was created in 1999 and the IMF is devoting an increasing amount of resources to crisis prevention. There has been a shift in the strategy of crisis prevention by the IMF. Mistakes had been made at the time of the Asian crises - mistakes in the assessment of sovereign debts, and hasty capital liberalization before a good supervision of banks and capital markets existed - and the role of flexible exchange rates as a measure of shock absorption has been neglected. Today, the Financial Sector Assessment Program together with the World Bank draws up profiles of the strength and weaknesses of the financial sector of a country. Standards for better statistics, transparency rules and supervisory standards are promoted by this programme. But one initiative which was started by the IMF has still not been realized: the author pleads for an international treaty which would facilitate the orderly resolution of sovereign debt crises. He ends optimistically: there will still be overshooting and its correction in the financial markets in the future, but this should become rarer and less severe by means of these measures.

\section{Chapter 4: Industrialization}

In the Böhm-Bawerk Lecture Sanjaya Lall deals with the problems of industrializing the poor countries in the globalized world based on his work for UNIDO's Industrial Development Report. He sees a cumulative and structural process of a growing wedge between a few successful countries and a large number of others. The cause lies in the problems of unevenly distributed immobile assets, which are necessary for developing, attracting 
the basis for developing: skills, work discipline, technological competence, supplier clusters, infrastructure and administrative capabilities. Developing countries as a group are doing well in the important arena of manufacturing exports and even - unexpected in theory - in high-technology exports! However, on the regional and on the country level there is a high concentration on a few successful countries, for instance, the East Asian nations on the one hand and Sub-Saharan Africa on the other, or Mexico in the Latin Americas. Also, contrary to neo-liberal theories, the author finds much evidence that government intervention has existed in the successful countries: selective interventions in most markets to guide resource allocations, for instance, FDIs, developing national capabilities, such as skills and R\&D, and take-over of new technologies. Up to now, there has been the autonomous way, developing R\&D and drawing-in of foreign technology, and the alternative, using FDI and transnational companies in the labour extensive products sector. For the future, however, there may be many 'roads to heaven' for the poor countries, and the same successful strategies may not necessarily be repeated. The developing countries need new, focused and intelligent strategies which have to be industry-specific, so that the strategy of the key players in each value chain becomes important for the integration of the global value chains.

\section{Chapter 5: Ability, Failures and Proposals for Reforms}

In a similar way to other contributors, Andreas Exenberger defines development as including economic as well as political and social elements. The role of international institutions is analysed according to the theory of Douglass North, who stresses the importance of adaptation of their rules, because it is necessary to adapt the institutions for changing conditions. By using the formulation of four different levels of social analysis by Oliver Williamson he distinguishes the level of the institutional environment (the constitutions and bureaucracy) and of the governance of this given framework for their implementation.

The empirical failure of the institutions in the last 40 years is analysed by a cluster analysis for the different elements of economic, social and political development. This analysis shows the break between the 'Northern' and the 'Southern' clusters, but no cluster for all dimensions. He distinguishes four groups: the advanced, the well developing, the developing and the nondeveloping countries (one-fifth of the total). The role of international institutions has been small or negligible in the examples of an extra-ordinary development - such as in China - and important in the countries of nondevelopment. This is the starting point for his proposals for reforms: 
- the UN should act as a governing body for the coordination to avoid transaction costs and duplication or even contradictions between the different institutions;

- more democracy: not only 'one vote-one state' but also double majorities (vote weight for population size);

- a change of rules for more participation of the whole community of states and NGOs;

- more precise definition of tasks (for example, what constitutes a market failure), and more transparency for reducing uncertainty and transaction costs;

- criteria for good governance, and independent tribunals with retaliations and reparation payments;

- some criteria should be handled as flexibly as possible, and incentives for improvements in human development should be added;

- stabilization of export revenues and relief for debt burdens; and

- more aid, even with a moderate form of global taxation.

The author is aware of the fact that these proposals are paradigmatic and therefore will take time. What is needed desperately is more legitimacy of the organizations and a clear distinction between the groups of countries. The nondeveloping countries do not need credits. The 'Washington consensus' is inadequate for their needs: they need grants and help. The developing group needs supervised credits and assistance. There should be a clear distinction between the agencies dealing with the different groups guided by an overall framework. However - in the sense of Williamson - it is not the organizations that are to blame for the bad performance of development, but the underlying institutions, which may have been appropriate for the post-war period, but which now have to be changed. A global discussion about this reform is necessary.

\section{Chapter 6: IMF Lending and Freedom Effects}

In their chapter Sevinç and Hakan Mihci test empirically whether the volume of IMF credits and loans and economic and political freedom have a positive influence on growth and therefore development. In their model they test these two relations for 34 countries.

The result for the IMF credits and loans is the same as in many other previous studies: there is a negative relation between the volume of credits and loans and growth performance. This can be explained by the demandrestrictive influence of IMF-adjustment programmes, which compensated the positive influence of credits and loans on investment. However, the authors admit that it may be possible in the long run that the effect of higher investment on productivity yields a positive effect on growth. 
The effect of economic freedom is found to be positive for growth, consistent with other previous studies. It is more important in middle-income countries. As an explanation for this fact they offer the thesis that improvements of economic freedom become effective only above some threshold level.

The result of the test of the influence of political freedom on growth is inconsistent with other studies: the authors do not find a positive impact. An explanation for this inconsistency may be that the panel of countries in their test includes only those countries which repeatedly got credits and loans from the IMF.

The authors conclude that the IMF does not seem to be playing a role in the improvement of the welfare levels of developing countries by means of providing loans and credits. This conclusion may be challenged with the argument that the Fund today has other tasks which may be more important for developing countries than credits and loans.

\section{PART II: PARTICULAR INTERNATIONAL INSTITUTIONS AND POVERTY}

\section{Chapter 7: WTO Membership}

After a review of the literature about the economic benefits of joining the WTO David Sapsford, V.N. Balasubramanyam and Stephan Pfaffenzeller develop an analytical framework for an evaluation. They apply this framework for an estimation of the possible benefits and costs of joining the WTO for Taiwan, which became a member in 2002. The analytical framework suggests that an increase in trade flows is neither a necessary nor a sufficient condition for a benefit in terms of growth. If the competitive advantages persist, Taiwan will experience a decline in heavy industry and the service sector, but gain in the non-heavy manufacturing sector. However, it cannot be assumed, as in the standard trade models, that the comparative advantages do not change by entering the WTO. And even when there is not a large benefit in terms of improved real incomes, the membership gives the participating countries an orderly rule-based process offering certainty and transparency for trade.

\section{Chapter 8: Critical Views on World Bank and IMF}

Kunibert Raffer describes very critically the long historical process of developing the goal and the instruments for poverty reduction of the World Bank and the IMF, with many examples of ineffective and contra-productive measures. 
It is clear that the goal of poverty reduction was not the original aim of the IMF and not the primary aim of the World Bank at their foundation. Gradually, however, this aim was becoming the prime goal of both institutions. Even the organizations themselves, for instance, the IMF, have admitted that there were many failures made to achieve this aim (see, for example, the contribution by Governor Klaus Liebscher in Chapter 3). But the two organizations have learnt a great deal. Also, there are still many suggestions (including those made in this book) to improve the efficiency of the institutions. In spite of this, Kunibert Raffer comes to the conclusion that both organizations are 'either unlikely to be really interested in fighting poverty or incapable of doing so'.

To give only one example of his arguments: he accuses the World Bank of having changed its strategy of evaluating projects from an economic costbenefit method to a more subjective assessment in an attempt to immunize against accountability. However, the former cost-benefit analysis had even been criticized by economists, because more 'soft' criteria - for instance, social factors, democracy and gender questions - should be included which are more difficult to measure than economic factors.

He explains the divergence between the declaration of 'poverty reduction' and the activity to be a marketing device in a Parkinsonian survival strategy of the two organizations. 'If poverty reduction were indeed as dear a goal to the international community as various declarations ... this important issue must not be left to the Bretton Woods institutions.' When he demands more grants and debt reductions - a demand which today comes from many countries - he leaves open the question as to whether the two existing institutions could be used for administering these measures. It is also left open as to whether the new function of these institutions as a 'think tank' or a 'knowledge bank' should be retained or not.

\section{Chapter 9: Poverty in the Transformation Path}

Mirjana Dragičević shows, in a similar way to former chapters, the failures made by international organizations in advising the transformation process, using the example of Croatia. The same failures had been made as in the transformation process of other countries: privatization too quickly, before a competition and regulatory framework was created; no awareness of the sequencing of the measures and of creating necessary institutions. These failures, together with the effects of the war, created a dramatic drop in the national income, but high rents for the elite and poverty for the masses. In a second stage in the transition some advice came from international institutions for building institutions. However, because they came from outside, the government was not open to a participatory process and raised barriers to change. 
One may object that the international organizations did not have experience with a transformation process: they had not been created for this difficult task. Even economic theory did not offer prescriptions for an optimal transformation. Only in the last few years, have theory and international organizations learnt from their failures. These remarks are also applicable to the two following chapters, which deal with the role of international institutions in transformation regions.

\section{PART III: INTERNATIONAL INSTITUTIONS AND REGIONAL ISSUES}

\section{Chapter 10: Transformation Regions}

Syed Ahsan and Melania Nica examine the growth and poverty development in 18 countries in transformation between 1987 and 2000, and the influence of institutions (the 'institutional capital') on these two aspects. Their main findings are that institutions have a very important role in explaining growth, and that growth may be dampened by a rising inequality. The latter finding is different to the results of other studies, which assert the importance of growth for reducing poverty. The authors find that only early in the transition phase, up to 1995, did growth have an influence on poverty, together with the initial inequality.

The conclusions of their empirical research for policy reforms are that there is a need for:

- distribution-friendly growth;

- sustainable public transfer schemes, such as social insurance;

- efficient worker training incentives for skill acquisitions;

- the promotion of self-employment; and that

- public authorities should encourage initiatives by NGOs for local provision of educational and health services.

\section{Chapter 11: Russian Privatization}

Alois Wenig discusses the Russian privatization process, which had brought poverty to the masses and tremendous wealth to the few managers who were able to gain ownership of the state enterprises. It was not the intention of the privatization law, but the managers profited from the fast liberalization of foreign payments and a corporate law which did not give enough rights to the shareholders to control the company. The managers could therefore strip the assets of the company, transfer the wealth abroad, and buy the shares from the workers and the public at very low prices. 
Wenig does not discuss the influence of international institutions, but it is known that they were in favour of a quick privatization with a "shocktherapy' because it was believed that a gradual approach would not succeed: according to Wenig, there would have been permanent struggles over the 'right' direction. Wenig's opinion fits into the hypothesis that a newly created democracy is not capable of a gradual transformation, which could have avoided the hardships of the 'big bang'.

\section{Chapter 12: Role of the IMF in the South-East Asian Crisis}

Teofilo Daquila describes the Asian crisis of 1997/98 and then asks whether the IMF fulfilled its role in this crisis. As is well known and well documented today, the IMF made many mistakes: it had insisted on keeping the exchange rate fixed, liberalized capital flows too quickly, gave credits for bailing-out and replenished foreign currency reserves. The conditions of the credits were a restrictive fiscal policy - a cure which had been the right one for countries with high budget deficits, but not for the East-Asian countries. Malaysia, which weathered the crisis better than Indonesia because it did not follow the prescriptions of the IMF, introduced capital controls and an expansionary monetary policy.

Most of the author's five proposals for better management of future crises have already been accepted by the IMF: rethinking the exchange rate; improving regulatory standards; bailing-in the private sector; and (not lifting) capital controls (too fast). Only the proposal for the creation of an international lender of last resort is still under discussion.

\section{Chapter 13: Development Crisis in Sub-Saharan Africa}

Kwan Kim states that the African crisis has been caused as much or perhaps more by the internal factors related largely to poor governance by often corrupt African governments; however, the focus of his chapter is on the external factors. Africa has been more affected by the changing global environment than other countries. Not content with the role of the international institutions and their neo-liberal paradigms, the author's proposals for the role of international institutions begin with abolishing agricultural protectionism and subsidies. The institutions have to play a more active role in developing a competitive export sector. The second task is debt relief. Third, more aid should be given, concentrated on education and health. Finally, the international institutions should promote region-based economic cooperation. The author ends with the example of the East Asian countries, which were in a similar economic condition 40 years ago to Africa today. Therefore, he concludes that African recovery 'is not impossible'. 